\title{
Professional development of school library staff in Trinidad and Tobago
}

\author{
Simone J. Primus \\ 7 Primco Drive, \\ Glencoe, Trinidad. \\ sjprimus@gmail.com
}

\begin{abstract}
Using a qualitative case study approach, this study explored the impact of participation in a virtual community of practice on the professional development of secondary school library staff in Trinidad and Tobago. Participants engaged in forum discussions, Web meetings, and online collaborative problem solving over a 12-week period. Preliminary findings suggest that participation in a virtual community of practice impacted participants in four areas: technical, social, cognitive, and tangible. School library practitioners and administrators could use this research to help them develop an informal ongoing professional development program.
\end{abstract}

\section{Introduction}

Members of a community of practice share a common interest and interact informally to expand their knowledge in a particular area. Communities of practice, widely used in business and industry to improve organizational performance, are currently gaining popularity in education (Wenger \& Snyder, 2000; Sherer, Shea, and Kristensen, 2003). Sherer et al. suggest this is because traditional means of connecting with peers as part of professional development, through conferences, workshops, phone calls, and lunches are insufficient for professionals in a rapidly changing knowledge environment. School librarianship is one profession in the throes of rapid change as school librarians "aren't merely no-nonsense book providers anymore. In the digital age, they are multitasking information managers - part teacher, part technologist" (Starkman, 2007, II 1).

Extensive research done internationally documents the positive impact a well-run school library media program, staffed with qualified professionals, has on student achievement (Library Research Service, 2011). The critical role of school libraries, acknowledged in the IFLA/UNESCO School Library Manifesto (2006), of helping young people to function successfully in today's knowledge-based society through life-long learning and critical thinking skills, requires school library staff (SLS) themselves to be lifelong learners and engaged in continuous professional development. In Trinidad and Tobago school libraries are woefully understaffed inhibiting the ability of its school library programs to effectively help students acquire the critical thinking and lifelong learning skills needed for success in the $21^{\text {st }}$ century. In light of the changing school library profession and the need for continuous professional development of SLS in Trinidad and Tobago, the researcher initiated and facilitated a virtual community of practice (VCOP) among secondary SLS to explore how participation in a VCOP impacts the professional development and self-reported efficacy as a school librarian in Trinidad and Tobago. Additionally, the research study sought to examine how Trinidad and Tobago SLS manage and share knowledge gained through participation in the VCOP. In the following sections I look at the literature in support of adult collaborative learning delineating effective elements for building a virtual community of practice for school librarians. For the purpose of this paper, the research methodology is presented however; a complete analysis of the data is still to be undertaken. As such, only an initial presentation and discussion of results is included.

\section{Professional development}

A rapidly changing school library profession points to a need for continuous professional development of existing staff. Research has shown however that sporadic, insular professional development opportunities are ineffective in bringing about a change in performance. Instead, it should be ongoing, provide opportunities for reflection and group inquiry into professional practice, and provide opportunities for peer interaction (Abdal-Haqq, 1996). Further, it should be embedded into one's work, provide follow up support, and incorporate constructivist approaches to teaching and learning. Harada's research (2001) is consistent with these findings adding that professional development should be a cooperative and social experience with "guided opportunities for discourse, practice, and reflection" (p. 14). She adds that the use of technology is 
fundamental to the delivery and implementation of professional development.

Professional development for teachers and SLS should be guided by theories of adult learning and development. The Knowles, Holton and Swanson (2005) model of teaching and learning respects the diversity of knowledge and experience adults bring to any learning situation. It recognizes that adults are capable of self-direction and are motivated to learn things that will help them cope with their daily lives. Coupled with the previously identified components of effective professional development, Knight (2002) argues that communities of practice should be encouraged as a primary form of professional development. Studies by Gray (2004) with a group of adult learning coordinators and by Githens (2007) with adults in the rehabilitation and disabilities services field document the benefits of participation in online communities of practice. The studies support the value of collegial connections for both novice and experienced professionals.

\section{Communities of practice}

The research on communities of practice shows it to be an effective form of knowledge building within a community. Through sharing, discussion, and problem solving participants in a community of practice negotiate new meaning for themselves (Wenger, 2004). As they pursue their common interest and interact over time, trust is developed freeing them to share knowledge and issues, and solve problems together. Communities of practice help participants with professional challenges, provide access to expertise and to a network for keeping abreast of the field (Wenger, McDermott, \& Snyder, 2002). Where communities interact via the use of technology, participants improve their online communication skills, their technical skills with various tools, their pedagogic skills involving collaborative learning, and their leadership skills (Riverin \& Stacey, 2008).

Wenger identified three essential elements of all communities of practice. The first, domain, is the area of interest that gives meaning to the group's presence. It is that common interest, as indicated earlier by Knowles et al., to learn something that will help improve their daily lives, that draws them together as they seek to develop knowledge in that subject. In the VCOP under study, the topic that provided content interest for the community was school library leadership with sub-topics in teaching and learning, instructional partnerships, program administration, and advocacy. Wenger's second essential element is community. People build community as they interact socially, developing relationships, which in turn fosters trust, with the freedom and willingness to share. The final element, practice, is what members of the community share and develop together. Members of the VCOP shared challenges, gave advice, shared resources and best practice.

As members of a community share knowledge and discuss key issues with the intention of improving or transforming their practice, learning takes place through the reflective process. A transformation occurs as ideas and practices are challenged (Brockbank, McGill, \& Beech, 2002). While independent reflection can be self-deceptive, the various perspectives presented during group interaction and reflection can potentially lead an individual to rethink his or her position (Brockbank et al., 2002). Reflection is however a process that takes time and to be successful requires individuals to be open to multiple perspectives but group interaction and problem solving through an examination of practice and beliefs can result in learning (York-Barr, Sommers, Ghere, and Montie, 2001).

One way of stimulating group interaction is through storytelling. This age old tradition is currently used to improve organizational performance and achieve strategic objectives. Different types of stories used with various storytelling techniques are told to spark action, communicate identity, foster collaboration, and share knowledge (Denning, 2004). Storytelling impacts both the listener and the storyteller. The listener may identify with a familiar experience but listening to a different perspective may build new knowledge as alternative solutions are explored (Rossiter, 2002; Tyler, 2007). The storyteller, through the retelling of a critical incident, retrospectively makes sense of behavior. Both the storyteller and the listener construct knowledge as they engage in reflection during the telling of a story. Work related challenges that participants shared were used to stimulate reflection and discourse in the VCOP.

\section{Knowledge management}

In this information age, organizations are concerned with getting information from those who have it to those who need it in an effort to improve organizational performance. Advances in technology and rapidly 
changing information require SLS to continually absorb new information and build knowledge as they seek to help students become lifelong learners in a digital environment. This may encompass the incorporation of new technologies in information management and assisting faculty to incorporate new instructional strategies as SLS demonstrate teacher leadership.

Two approaches to knowledge building and management are evident in the literature: (a) the informational, and (b) the personal or interactive (Demarest as cited in Iverson \& McPhee, 2002). The informational approach aligns with explicit knowledge expressed as the direct evidence of knowledge such as tools, documents, and procedures. Electronic databases and networks are currently used to capture, sort, organize and store this type of information for use in the future. A study by Cross, Parker, Prusak, and Borgatti (2001) found however, that persons more frequently sought information from colleagues than from impersonal sources of information. This is supported by Rosenberg (2003) who asserts, "we learn from one another more often than we do from any other source, and that will never change" (41).

The personal exchange of knowledge among people is the core of the second approach to knowledge management and is generally how implicit knowledge is imparted. Key understandings, values and beliefs that reside in individuals can be shared through storytelling and dialog but Wenger, McDermott, and Snyder (2002) posit that knowledge is truly defined through the discussion, disagreement, and consensus building that occurs among members of a community. In a community of practice, members interact in discussions around a common domain of knowledge. They share their practice, their tools, their documents and artefacts.

\section{Computer mediated communication}

Advances in information communication technologies can facilitate the interaction necessary for a community of practice to thrive, particularly for those community members separated by time and place. In a VCOP community members interact in a primarily online format thus the literature that supports a community of practice also supports a VCOP with the addition of design features for online usability and sociability, which will be examined in this section on computer mediated communication. In addition I examine how computer mediated communication supports knowledge transfer.

The transfer of both tacit and implicit knowledge is necessary in any organization. Any electronic system that supports community building therefore must support an exchange of information and social interaction and include a system of file management and communication. The system must be designed for sociability human interaction, and usability - the human computer interaction (Preece, 2000). It must support interaction between and among community members, between community members and content, and between community members and the instructor/community facilitator. Further, it must support internalization through reflection on the community's dialog and externalization or an outward evidence of knowledge construction (Novak and Wurst, 2004).

Designing for usability means the online communication interface must be easy to use as well as useful. It must allow for the production and presentation of artefacts or the evidence of the community's practice. The database should be simple and relevant with a powerful search engine (Bansler and Havn, 2003; Schlager \& Fusco, 2003; McAndrew, Clow, Taylor, and Aczel, 2004). The site should be visually appealing with graphics and color used as a guide within postings for community members (Palloff and Pratt, 2007).

The cornerstone of learning in community is interaction among members thus designing for sociability is critical in the development of a VCOP. Garrison and Anderson (2003) support Preece's assertion on sociability stressing the need to develop a social presence, a cognitive presence and a teaching presence. For learning in an online community to be successful, community members must feel free to share their stories, expressing their ideas, opinions, and emotions. Building social presence and developing trust takes time but is essential if community members are to construct meaning through reflection and dialog or develop cognitive presence (Garrison and Anderson, 2003). Palloff \& Pratt (2007) and Simonson, Smaldino, Albright \& Zvacek (2006) recommend an initial face-to-face meeting so participants can get to know each other. An opportunity to continue relationship building should exist in the online portal perhaps in an online lounge or café.

Once a social presence is established developing content presence occurs as community members discuss issues, share problems, exchange information and solve problems around their area of common interest. 
Teaching presence becomes evident as the community facilitator poses questions to the community, focuses discussion and weaves arguments together. Social presence and cognitive presence are woven together by the facilitator in his or her social function as he or she works to create a nurturing environment. The multifaceted role of the facilitator includes managing community logistics such as the times of web conferences or chats and developing the communication protocol. The facilitator also works to help community members become comfortable with the technology. Githens (2007) and Gray (2004) investigated the importance of the facilitator's roles identifying the community facilitator as essential in developing, sustaining, and enhancing the learning function of the community.

Information communication technologies today are well suited to support collaboration, communication, problem solving and decision-making in a VCOP. Features that support communication include discussion forums, chat rooms, instant messages, email, and blogs so members can communicate in both real and delayed time (Apostolou, Mentzas, Baraboutis, and Papadopoulou, 2004) . Where synchronous communication is needed video and audio Web conferences are options. When collaboration is called for, a document management system can be used as well as a project workspace for exchanging information. When decisions must be made a voting forum or chat rooms can be used.

The use of online communities of practice to build knowledge and improve organizational performance has primarily been investigated within business or industrial communities (Wenger \& Snyder, 2000). While some research has been conducted among education communities (Sherer, Shea, and Kristensen, 2003), and public and academic libraries (Guthrow, 2004), there is a lack of empirical evidence on the impact of participation in VCOPs amongst the school library profession. This study seeks to answer two broad research questions: (1) How can school library professionals effectively use a virtual community of practice? (2) How could participation in a virtual community of practice contribute to the professional development of Trinidad and Tobago school library staff? This qualitative research study is expected to add to the literature on communities of practice and on the professional development of school library professionals through its unique combination of participants. The researcher expects from studying the phenomenon to find that sharing professional experiences and collaborative problem solving will contribute to the key success factors in the professional development of SLS in Trinidad and Tobago.

\section{Methodology}

This qualitative case study was conducted with a group of 11 secondary SLS of the National Library and Information System Authority of Trinidad and Tobago (NALIS). Participants were purposely selected with the assistance of NALIS School Library Services administration. The VCOP was implemented for 12 weeks during which the participants engaged in several activities including a face-to-face orientation, online forum discussions, live Web meetings, sharing of professional challenges, collaborative problem solving, and sharing best practice and artifacts. The topic area for engagement in the VCOP was school library leadership. The small number of participants engaged in this study means that the findings cannot be generalized to other contexts.

\section{Participants}

The participants in this study were secondary school librarians with varying professional classifications and qualifications. A combination of maximum variation and criterion sampling was used to select informationrich participants (Patton, 1990). All 11 participants were in charge of managing their school's library. Participant diversity was represented through levels of qualification, experience, and geographic location. Table 1 provides background information on the 11 SLS. Pseudonyms are used to maintain participant confidentiality.

Table 1. Participant Background

\begin{tabular}{llll}
\hline Participant pseudonym & Years SLS service & Classification & Qualification \\
\hline Morgan & 1 & Librarian 1 & $\begin{array}{l}\text { Non-Library Bachelor's } \\
\text { Degree }\end{array}$ \\
Jordan & 2 & Librarian 1 & $\begin{array}{l}\text { Master's Degree in Library } \\
\text { and Information Science }\end{array}$
\end{tabular}




\begin{tabular}{|c|c|c|c|}
\hline Taylor & 7 & Librarian I (ag). & $\begin{array}{l}\text { Associate Degree in } \\
\text { Library and Information } \\
\text { Studies. }\end{array}$ \\
\hline Leslie & 5 & Librarian I (ag). & G.C.E. A' levels \\
\hline Lou & 16 & Librarian I (ag). & $\begin{array}{l}\text { Certificate in Education } \\
\text { for Librarians }\end{array}$ \\
\hline Jessie & 7 & Librarian 1 & $\begin{array}{l}\text { Non-Library Bachelor's } \\
\text { Degree }\end{array}$ \\
\hline Pat & 10 & School Librarian 11 & Masters in Library Science \\
\hline Sydney & 2 & Librarian 11 & Masters in Library Science \\
\hline Alva & 21 & Librarian II & $\begin{array}{l}\text { Non-Library Bachelor's } \\
\text { Degree }\end{array}$ \\
\hline Shelby & 4 & Librarian I (ag). & $\begin{array}{l}\text { Non-Library Bachelor's } \\
\text { Degree }\end{array}$ \\
\hline Devon & 15 & Librarian 1 & $\begin{array}{l}\text { Non-Library Bachelor's } \\
\text { Degree }\end{array}$ \\
\hline
\end{tabular}

Participants represented six of the eight education districts across the country and their school enrolment ranged from 420 to 1200 . Two males and nine females with ages ranging between 33 and 50 participated in the study.

Drawing from information in the literature review, the research study engaged participants in a VCOP on the topic of school library leadership. The researcher initiated the community with a face-to-face orientation where participants met each other and were introduced to the community Web portal through which communication and collaboration occurred. Following this, the participants engaged in eleven weekly sessions facilitated by the researcher. Bi-weekly synchronous online Web meetings allowed participants to speak in real time with their colleagues from their various work places while asynchronous forum discussions enabled participants to interact with their colleagues at their convenience. The facilitator, herself an experienced school library professional, initiated discussions on contemporary issues in school library leadership through the use of content triggers such as brief articles and videos, followed by broad discussion questions. Participants were also able to communicate and share with each other via a social blog and the Web portal contained an area for sharing resources such as Web links, documents, photographs, and other media. A snapshot of the portal's home page is presented in Figure 1.

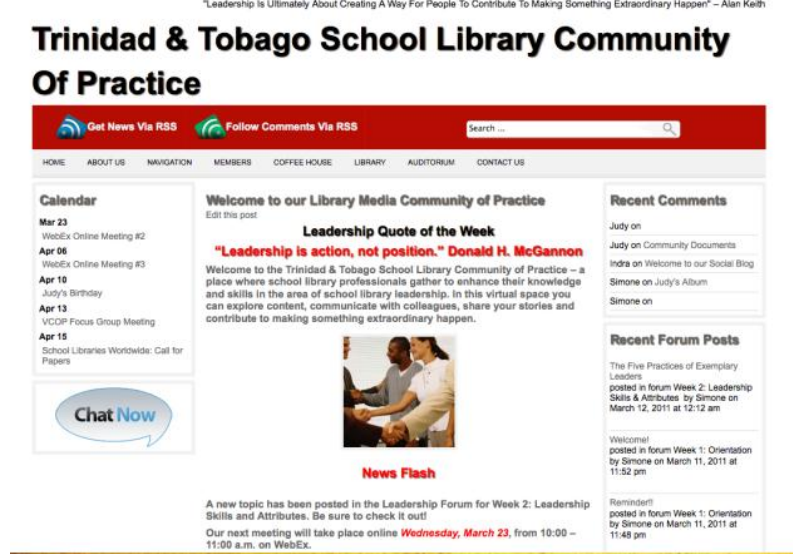

Figure 1. Screenshot of home page

Topics for discussion were posted in the forum every other week with participants encouraged to engage in 
dialog through their postings to the forum. Web meetings took place during the week following the initial topic posting in the forum providing additional opportunity for participants to discuss the previous week's topic. During the meeting one participant generally shared their work-related challenge. This was an integral part of the VCOP that was used to stimulate further discussion and build community. Participants were given a template they could use to help them prepare their story and were asked to describe some challenge they had previously faced, how they dealt with it and to reflect upon alternative solutions to the problem. Table 2 presents an outline of the discussion topics.

Table 2. Virtual Community of Practice Topic Overview

Week Topic

1

Orientation (F2F)

- Overview of research study

- Orientation to the VCOP portal

2

Leadership skills \& attributes (Synchronous)

- The 5 practices of exemplary leadership

- School library leadership

Leadership through Teaching \& Learning

- Information literacy \& learning in multiple formats

- Reading advocacy

Storytelling (Synchronous)

5

Leadership through Instructional Partnerships

- Faculty - LMS Collaboration

- Staff Development \& Instructional Technology facilitation

6

Storytelling (Synchronous)

7

Leadership through Program Administration

- Vision \& Mission

- Strategic Planning

- Public relations

Storytelling (Synchronous)

Leadership through Advocacy

- Contributing to the profession

Storytelling (Synchronous)

11

Open Discussion

- Participants suggest topics for discussion

Wrap up: Where do we go from here? (Synchronous)

\section{Data collection and analysis}

Data for the study were gathered from three main sources: a focus group interview, digital documents, and personal interviews. Six participants engaged in the focus group midway through implementation of the VCOP. Questions were designed to elicit feedback to assist with improving the VCOP. The second source of data came from four participants who were individually interviewed at the conclusion of the VCOP. The 
interviews were designed to:

- Gauge the overall impact of participation

- Determine the benefits of participation in the VCOP

- Ascertain the kinds of knowledge shared and developed

- Ascertain the level of satisfaction with the VCOP as a means of informal professional development. Transcripts were sent for member checking after the interviews to ensure validity of the data. The third source of data came from transcripts of forum discussions and the bi-weekly Web meetings. The transcripts provided evidence of community interaction and participant reflection and learning.

The focus of the data analysis for this article is to determine how participation in the VCOP contributed to the professional development of SLS. The researcher conducted content analysis of the data. "Content analysis, when conducted with an aim to understanding the learning process, provides information on the participants as learners, and on their ways of dealing with a given topic" (Henri, 1991, p. 118). A constant comparative method of analysis was used to triangulate data from the different interview transcripts and to identify emerging themes related to how participation in the VCOP contributes to SLS professional development. In addition, Gunawardena, Lowe, and Anderson's (1997) interaction analysis model (IAM) will be used to analyze the digital documents. The IAM was designed to help with understanding and describing "the process of negotiating meaning and knowledge construction in a collaborative online discussion environment" (Marra, Moore, \& Klimczak, 2004, p. 25). It is also one of the most used content analysis models (Marra et al.).

\section{Findings and discussion}

In this section, the researcher presents preliminary findings in response to the primary research question on the impact of participation in a VCOP on the professional development of Trinidad and Tobago SLS. The findings and discussion are presented according to three specific research questions:

- What key success factors contribute to the self-reported benefits of participating in a VCOP?

- What impact does participation in the VCOP have on Trinidad and Tobago SLS?

- How satisfied are SLS with a VCOP as a means of professional development?

\section{Community participation}

Levels of participation in the VCOP were as diverse as the participants involved. Only one of the participants had extensive experience with social learning networks but as expected some participants contributed extensively while others hardly participated at all. Of the eleven participants who participated in the study, one participant ceased to contribute to the community after her initial orientation forum post. Two participants were unable to participate in the synchronous Web meetings during working hours due to vandalism of their school's Internet service and the inability to have the necessary application installed on the school's computer. They were both however able to contribute to the discussion forum. This points to a sound technological infrastructure as key to a functioning VCOP. One participant made no contributions to the forum after the orientation session and only participated in one Web meeting. Over the 12 weeks the number of posts to the forum made by any one participant ranged from two to 20 . Individual contributions to Web meetings ranged from six to 46 with contributions defined as each instance a participant engaged in critical content dialog with VCOP members i.e. sharing information, elaborating on colleagues contributions, expressing disagreement or agreement supported by a rationale, and making suggestions.

This researcher found the level of posting to the discussion forum surprisingly low. The community was designed with the expectation that the majority of discussions would occur in the forum, the advantage being that participants could post at their convenience. However, participants' excitement at the opportunity to interact with colleagues during synchronous Web meetings is evident in the statement, "just having somebody else to speak to and to vent and to voice your concerns, issues and recommendations and suggestions in a confidential environment was great." School librarianship can be an isolating profession as in many schools there is only one professional staff member. This perhaps is one explanation for the higher number of contributions in Web meetings as compared to forum posts. It could also be due to the interpersonal nature of the Trinidad and Tobago culture. One participant indicated that they were unaccustomed to the online environment and just needed time to get used to the system while others indicated that work commitments impacted on time to dedicate to forum posts. Disappointment was expressed by the more active participants in the forum at the seeming lack of commitment by others to post. 
They indicated that it might have been a discouragement to others. A greater examination of the impact of cultural on a school library VCOP is perhaps needed.

\section{Benefits and impact of VCOP participation}

A comparison of interview responses revealed four emerging themes with respect to the benefits and impact of participating in a VCOP. Participants identified an impact on their level of engagement with technology; a social impact through the formation and development of professional relationships and friendships; a cognitive impact through professional stimulation; and a tangible impact in the practical ideas to improve their school library programs. Each of these will now be discussed.

As a school library professional, each of the participants is exposed to the use of technology at their work site. Responses to a background information survey however revealed that while nine participants expressed some level of comfort with Web 2.0 and ICT technologies, two participants indicated they had no experience in this area. It is notable that these were the two participants previously identified as having little interaction with the community. Two of the four participants who were interviewed stated that participation in the VCOP increased their engagement and level of comfort with technology and in the words of one participant, "it gave me a reason to use the technology". Another participant took the opportunity to experiment using different types of media and stated:

I always wanted to find one of the technologies that would allow you to share information across a diverse group of people...I like the technology and I really wanted to share so there was one night when I sat up the whole night. I went to bed around 4 o'clock. I wanted to learn to use the technology so I tried different things.

These findings support Riverin and Stacey (2008) who found that where communities interact via technology, participants improve their online communication skills and their technical skills with various tools.

All of the participants interviewed identified the social impact of participation in the VCOP as significant.

The formation of positive collegial relationships served to:

- Reduce isolation

- Increase confidence

- Provide a support group

- Motivate participants to network with other colleagues

- Improve relationships with other colleagues both at their school and within the community

The value to the community was expressed as:

I think I need to get out there and meet other school librarians. We need to meet each other and this forum brought that to the fore. We need to know who is who and we need to have more sessions like this.

Three of four participants interviewed identified the cognitive impact of participation in the VCOP. They commented that participation stimulated their thinking about and interest in their profession. The important role of the community facilitator as identified by Githens (2007) and Gray (2004) was repeatedly highlighted with reference made to the articles used to stimulate discussion. In the words of one participant:

I would say it [participation] also opened me up to a wide range of information because I found that when a topic was thrown out, like when you gave us an article to read, I would sometimes do extra reading on those areas, like when you throw out school library leadership, I would read something about it so it helped me to do some extra research and helped me to begin to think about topics - it stimulated interest in other areas.

One participant pointed out that interaction with the community helped her recognize some of her deficiencies and provided some ideas to rectify them. The community also reinforced some of the things she was already doing. Most revealing perhaps is this comment by one participant:

I really do enjoy working in the library and I was beginning to feel I was in a rut and stuck there but now I realize there is so much more to working in the school library. So it [the VCOP] gave me a 
little motivation.

A more tangible aspect of cognitive impact of participation in the VCOP was identified in the number of ideas and best practice shared in the community. Participants shared practical ideas on promoting the school library, ideas on partnering with teachers to implement their Information Literacy curriculum, ideas on reading and other programs, and for collaborating with the school community.

\section{VCOP as a means of informal professional development}

Participants were interviewed about the experience of learning in the VCOP as compared to learning in a formal workshop, class or seminar. While they saw the need for formal workshops, there was a mix of responses about their effectiveness. Two participants commented about the intense nature of workshops and the overwhelming feeling upon their conclusion. Another commented that a mix of a formal workshop followed by an opportunity for community interaction such as in the VCOP would be ideal. All participants interviewed applauded the interactive nature of the VCOP as a form of professional development. They expressed satisfaction with the VCOP as a form of professional development because:

- The learning was convenient and could take place at any time and place

- There was the freedom to share meaningful issues without the presence of supervisors

- It provided the opportunity to process thoughts and information

Satisfaction with the VCOP as a means of professional development is summed up in the words of one participant, "because this is an ongoing community I think it makes for a better processing of information and makes the learning even better".

\section{Conclusion}

In this research study, the researcher successfully initiated and facilitated a VCOP among secondary SLS to explore how participation in a VCOP impacts the professional development and self-reported efficacy as a school librarian in Trinidad and Tobago. Additionally, the research study sought to examine how Trinidad and Tobago SLS manage and share knowledge gained through participation in the VCOP. The data pointed to four primary areas of impact: (1) a technical impact, (2) a social impact, (3) a cognitive impact, and (4) a tangible impact. This study supports Etienne Wenger's work with communities of practice however, due to the small sample size the study cannot be generalized to other contexts. Given the time constraints of the study it was not possible to establish a long-term performance impact on either the participants or their organization. A long-term study in this area may provide useful results.

\section{Three key learnings:}

- Virtual communities of practice can reduce a sense of isolation among a dispersed group of school library professionals.

- Sharing ideas and information and collaboratively solving problems in a VCOP can stimulate school library staff in Trinidad and Tobago to learn more about their professional practice.

- The role of the community facilitator is critical in building both a social presence and a cognitive presence in a VCOP.

\section{References}

Abdal-Haqq, I. (1996). Making time for teacher professional development. Retrieved from ERIC database. (ED400259)

Apostolou, D., Mentzas, G., Baraboutis, K., \& Papadopoulou, S. (2004). Facilitating knowledge exchange and decision-making within learning networks. Journal of Universal Computer Science, 10(3), 205226.

Bansler, J. P., \& Havn, E. C. (2003). Building community knowledge systems: An empirical study of ITSupport for sharing best practices among managers. Knowledge and Process Management, 10(3), 156-163. doi: 10.1002/kpm.178

Brockbank, A., McGill, I., \& Beech, N. (Eds.). (2002). Reflective learning in practice. Aldershot, UK: Ashgate.

Cross, R., Parker, A., Prusak, L., \& Borgatti, S. P. (2001). Knowing what we know: Supporting knowledge 
creation and sharing in social networks. Organizational Dynamics, 30(2), 100-120.

doi:10.1016/S0090-2616(01)00046-8

Denning, S. (2004). Telling tales. Harvard Business Review, 82(5), 122-129.

Garrison, D. R., \& Anderson, T. (2003). E-learning in the 21st century [electronic resource]: A framework for research and practice. Retrieved from

http://www.netlibrary.com.ezproxylocal.library.nova.edu/Details.aspx

Githens, R. P. (2007). Understanding interpersonal interaction in an online professional development course. Human Resource Quarterly, 18(2), 253-274. doi:10.1002/hrdq.1202

Gray, B. (2004). Informal learning in an online community of practice. Journal of Distance Education, 19(1), 20-35.

Gunawardena, C. N., Lowe, C. A., \& Anderson, T. (1997). Analysis of a global online debate and the development of an interaction analysis model for examining social construction of knowledge in computer conferencing. Journal of Educational Computing Research, 17(4), 397-431.

Guthrow, C. P. (2004). An analysis of the use of virtual communities of practice in managing knowledge for professional development by Oberlin Group librarians (Doctoral Dissertation). Nova Southeastern University, Fort Lauderdale, FL.

Harada, V. H. (2001). Professional development as collaborative inquiry. Knowledge Quest, 29(5), 13-19.

International Federation of Library Associations. (2006). IFLA/UNESCO school library manifesto. Retrieved from http://archive.ifla.org/VII/s11/pubs/manifest.htm

Iverson, J. O., \& McPhee, R. D. (2002). Knowledge management in communities of practice: Being true to the communicative character of knowledge. Management Communication Quarterly, 16(2), 259-266. doi: $10.1177 / 089331802237239$

Knight, P. (2002). A systemic approach to professional development: Learning as practice. Teaching and Teacher Education, 18, 229-241. doi:10.1016/S0742-051X(01)00066-X

Knowles, K., Holton, E. F., \& Swanson, R. A. (2005). The adult learner: The definitive classic in adult education and human resource development. Retrieved from http://lib.myilibrary.com/Browse/open.asp?ID=100997\&loc=68

Library Research Service (2011). School library impact studies. Retrieved from http://www.lrs.org/impact.php

Marra, R. M., Moore, J. L., \& Klimczak, A. K. (2004). Content analysis of online discussion forums: A comparative analysis of protocols. Educational Technology Research and Development, 52(2), 23-40. doi:10.1007/BF02504837

McAndrew, P., Clow, D., Taylor, J., \& Aczel, J. (2004). The evolutionary design of a knowledge network to support knowledge management and sharing for lifelong learning. British Journal of Educational Technology, 35(6), 739-746. doi:10.1111/j.1467-8535.2004.00431.x

Novak, J., \& Wurst, M. (2004). Supporting knowledge creation and sharing in communities based on mapping implicit knowledge. Journal of Universal Computer Science, 10(3), 235-251.

Palloff, R. M., \& Pratt, K. (2007). Building online learning communities: Effective strategies for the virtual classroom. Retrieved from http://lib.myilibrary.com.ezproxylocal.library.nova.edu/browse/open.asp?id=91603\&loc=

Patton, M. (1990). Qualitative evaluation and research methods (2nd ed.). Beverly Hills CA: Sage. 
Preece, J. (2000). Online communities: Designing usability, supporting sociability. West Sussex, England: John Wiley \& Sons.

Riverin, S., \& Stacey, E. (2008). Sustaining an online community of practice: A case study. Journal of Distance Education, 22(2), 43-58.

Rosenberg, M. J. (2003). Redefining e-Learning. Performance Improvement, 42(3), 38-41. doi:10.1002/pfi.4930420307

Rossiter, M. (2002). Narrative and stories in adult teaching and learning. Retrieved from ERIC database. (ED473147)

Schlager, M., \& Fusco, J. (2003). Teacher professional development, technology, and communities of practice: Are we putting the cart before the horse? The Information Society, 19(3), 203-220. doi:10.1080/01972240309464

Sherer, P., Shea, T. P., \& Kristensen, E. (2003). Online communities of practice: A catalyst for faculty development. Innovative Higher Education, 27(3), 183-194. doi:10.1023/A:1022355226924

Simonson, M., Smaldino, S., Albright, M., \& Zvacek, S. (2006). Teaching and learning at a distance: Foundations of distance education (3rd ed.). Upper Saddle River, NJ: Pearson Education.

Starkman, N. (2007). The new librarians [Electronic version]. T.H.E. Journal. Retrieved from http://www.thejournal.com/articles/21080_5

Tyler, J. A. (2007). Incorporating storytelling into practice: How HRD practitioners foster strategic storytelling. Human Resource Development Quarterly, 18(4), 559-586. doi:10.1002/hrdq.1219

Wenger, E. (2004). Knowledge management as a doughnut: Shaping your knowledge strategy through communities of practice. Ivey Business Journal, 68(3), 1-8.

Wenger, E., McDermott, R. A., \& Snyder, W. (2002). Cultivating communities of practice: A guide to managing knowledge. Retrieved from http://www.netlibrary.com.ezproxylocal.library.nova.edu/Reader/

Wenger, E. C., \& Snyder, W. M. (2000). Communities of practice: The organizational frontier. Harvard Business Review, 78(1), 139-145.

York-Barr, J., Sommers, W. A., Ghere, G. S., \& Montie, J. (2001). Reflective practice to improve schools: An action guide for educators (2nd ed.). Thousand Oaks, CA: Corwin Press.

\section{Statement of Originality}

This statement certifies that the paper above is based upon original research undertaken by the author and that the paper was conceived and written by the author(s) alone and has not been published elsewhere. All information and ideas from others is referenced. 